\title{
Sigma Ligands Indirectly Modulate the NMDA Receptor-Ion Channel Complex on Intact Neuronal Cells via $\sigma 1$ Site
}

\author{
H. Yamamoto, ${ }^{1}$ T. Yamamoto, ${ }^{1,2}$ N. Sagi, ${ }^{1}$ V. Klenerová,' K. Goji, ${ }^{1}$ N. Kawai, ${ }^{1,3}$ A. Baba, ${ }^{1,3}$ E. Takamori, ${ }^{1,3}$ \\ and T. Moroji ${ }^{1}$ \\ 'Department of Psychopharmacology, Tokyo Institute of Psychiatry, Tokyo, 'Laboratory of Molecular Recognition, \\ Graduate School of Integrated Science, Yokohama City University, Yokohama, and ${ }^{3}$ Psychiatric Service, University of \\ Tsukuba Hospital, Tsukuba, Japan
}

\begin{abstract}
To investigate the modulatory effects of $\sigma$ ligands on the $\mathrm{N}$ methyl-D-aspartate (NMDA) receptor-ion channel complex in vivo, we examined the intact cell binding of ${ }^{3} \mathrm{H}-\mathrm{N}-[1$ - (2-thienyl)cyclohexyl]piperidine $\left({ }^{3} \mathrm{H}-\mathrm{TCP}\right)$ to cultured neuronal cells prepared from fetal rat telencephalon. The ${ }^{3} \mathrm{H}-\mathrm{TCP}$ binding was saturable, reversible, and inhibited by a selective NMC.A receptor antagonist, D-amino-5-phosphonovaleric acid. Ni::limolar $\mathrm{Mg}^{2+}$ inhibited ${ }^{3} \mathrm{H}$-TCP binding both in the absence and presence of L-glutamate. 5-Methyl-10,11-dihydro-5Hdibenzo [a,d]cyclohepten-5,10-imine maleate (MK801) inhibited ${ }^{3} \mathrm{H}-\mathrm{TCP}$ intact cell binding in a competitive manner, while haloperidol inhibited it in a noncompetitive manner. The effect of the test drugs to inhibit ${ }^{3} \mathrm{H}$-TCP intact cell binding was in the order of dextromethorphan, haloperidol > $( \pm)$ MK $801>(+)$ pentazocine $>(-)$ pentazocine $>$ DTG $>$ PCP $>$ (+)-N-allylnormetazocine $[(+)$ SKF 10047] $>$ (+)3-(3hydroxyphenyl)- $N$-(1-propyl)piperidine $[(+) 3-P P P]>(-) S K F$ $10047>(-) 3-P P P$. The $I C_{50}$ values of the six $\sigma$ ligands for ${ }^{3} \mathrm{H}-\mathrm{TCP}$ binding were closely correlated with the $K_{i}$ values of the corresponding drugs for DTG site 1 in the guinea pig brain reported by Rothman et al. (1991). These findings suggest that the $\sigma$ ligand indirectly modulates the NMDA receptor ion channel complex, presumably through $\sigma 1$ sites in vivo as well as in vitro.
\end{abstract}

[Key words: antipsychotic, ion channel, intact cell binding, NMDA receptor, $\sigma 1$, primary culture]

The therapeutic efficacy of antipsychotic drugs is thought to be related to their potency in inhibiting dopaminergic transmission along mesolimbic and mesocortical pathways. However, the effective drugs are known to induce extrapyramidal side effects that may be due to the blockade of the D2 subclass of postsynaptic dopamine (DA) receptors in the striatum. Thus, an ideal antipsychotic drug would principally influence the cognitive and affective symptomatology of psychosis, and lack extrapyramidal side effects.

\footnotetext{
Received May 5, 1994; revised June 30, 1994; accepted July 14, 1994.

We express our thanks to Dr. T. Hama (Mitsubishi Kasei Institute of Life Sciences) for technical advice on preparing the primary cultured neuronal cells and to Mr. M. Okuwa (Sionogi Pharmaceutical Company Ltd.) for editorial assistance. This study was supported by a Grant-in-Aid for Scientific Research (No. 04770127) from The Ministry of Education, Science and Culture of Japan.

Correspondence should be addressed to Dr. H. Yamamoto, Department of Psychopharmacology, Tokyo Institute of Psychiatry, 2-1-8 Kamikitazawa, Setagaya-ku, Tokyo 156, Japan.

Copyright (C) 1995 Society for Neuroscience $0270-6474 / 95 / 150731-06 \$ 05.00 / 0$
}

The search for an understanding of psychotimimetic opiates led to identification and characterization of $\sigma$ binding sites. Additionally, the evidence showing that some antipsychotic drugs (e.g., haloperidol and remoxipride) bind to $\sigma$ binding sites with high affinity ( $\mathrm{Su}, 1982$; Tam and Cook, 1984; Largent et al., 1986; Ferris ct al., 1991) has opened new strategies for developing a new class of antipsychotic drug, devoid of actions at DA receptors, that possesses selective high affinity for $\sigma$ binding sites.

$N$-allylnormetazocine (SKF-10,047), a prototypic benzomorphan, and PCP were originally thought to elicit psychotimimetic effects via a common receptor, designated the $\sigma / \mathrm{PCP}$ site. However, subsequent studies demonstrated that the $\sigma$ binding sites are distinct from PCP binding sites (PCP receptor) located within the cation channel of the $N$-methyl-D-aspartate (NMDA) receptor ion channel complex (Quirion et al., 1987; Deutsch et al., 1988; Church and Lodge, 1990; Sanger et al., 1991). Based on data obtained from biochemical and radioligand-binding experiments, subtypes of $\sigma$ binding sites have been classified into at least two types designated $\sigma l$ and $\sigma 2$, though the physiological roles for these two subtypes remains to be clarified (Walker et al., 1990).

Selective $\sigma$ ligands such as $(+) 3$-[3-hydroxyphenyl]- $N$-(1-propyl)-piperidine [(+)3-PPP] and 1,3-di-(2-tolyl)guanidine (DTG) have been reported to modulate the NMDA response either in vitro or in vivo experiments. Using intracellular and extracellular recording techniques, Malouf et al. (1988) have shown that although PCP blocks the pyramidal cell response to NMDA at behaviorally relevant concentrations (1-10 $\mu \mathrm{M}),(+) 3-P P P(1$ $\mu \mathrm{M}$ to $1 \mathrm{mM}$ ) enhances excitations in CAl hippocampal pyramidal cells mediated by NMDA. DTG $(1-10 \mu \mathrm{M})$ reverses or inhibits the enhancement of the NMDA response by (+)3-PPP, while application of $100 \mu \mathrm{M}$ of DTG alone to the bath has no effect on the NMDA response. On the other hand, Monnet et al. (1992) have reported that DTG increases the neuronal firing activity induced by microiontophoretic application of NMDA to the rat CA3 dorsal hippocampus when injected intravenously at low doses ranging from 0.5 to $3 \mu \mathrm{g} / \mathrm{kg}$. At low doses that do not by themselves affect the NMDA response, haloperidol, $(+) 3-$ PPP, and a-(4-fluorophenyl)-4-(5-fluoro-2-pyrimidinyl)-1-piperidinebutanol (BMY-14802) reverses DTG-induced potentiations of the NMDA response. The reason for the discrepancy between the above-cited observations is not clear, but may be attributable to differences in the experimental procedures used, i.c., the in vitro and in vivo cxpcriments. Using cultured neuronal cells prepared from the fetal rat telencephalon, thus, we ex- 
amined the modulation of the NMDA response by $\sigma$ ligands to investigate the interaction of $\sigma$ ligands with the NMDA receptorion channel complex in vivo.

\section{Materials and Methods}

Materials. ${ }^{3} \mathrm{H}-\mathrm{N}$-[1-(2-thienyl)cyclohexyl]piperidine ( ${ }^{3} \mathrm{H}-\mathrm{TCP}, 1839 \mathrm{GBq} /$ mmol) was purchased from New England Nuclear (Boston, MA). PCP and 5-methyl-10,11-dihydro-5H-dibenzo[a,dlcyclo-hepten-5,10-imine maleate (MK-801) were donated from Shionogi Pharmaceutical Co. Ltd. (Osaka, Japan). Pentazocine was donated from Taisho Pharmaceutical Co. Ltd. (Saitama, Japan). Tetrodotoxin (TTX) and dextromethorphan were purchased from Sigma Chemical Co. (St.Louis, MO). NMDA and D-amino-5-phosphonovaleric acid (APV) were purchased from Cambridge Research Biochemicals, Ltd. (Harston, Cambridge, England). DTG, (+)3-PPP and SKF 10,047 were obtained from Research Biochemicals Inc. (Natick, MA). Other chemicals were purchased from commercial sources.

Cell culture. Primary neuronal cell cultures were prepared by mechanoenzymatic dissociation of the fetal rat telencephalon, according to a modification of the method described by Yuzaki et al. (1990). In brief, the rat embryos of gestational days 18 or 19 were removed under ether anesthesia, and then the telencephalon, including the cortex, hippocampus, and striatum, was dissected out and freed from the meninges. Following treatment with trypsin $\left(0.25 \%\right.$, Difco) in $\mathrm{Ca}^{2+} / \mathrm{Mg}^{2+}$-free phosphate buffered saline (CMF-PBS) containing 0.02\% DNase I (Sigma) for $15-20 \mathrm{~min}$ at $37^{\circ} \mathrm{C}$ on the shaker, the enzyme solution was removed by aspiration. To inactivate the residual enzyme, a mixture of equal parts of Dulbecco's modified Eagle's medium (DMEM) and the heat-inactivated horse serum was added to the cells. The cells were mechanically dispersed by repetitive pipetting and filtered through a nylon mesh to remove undissociated cells. The cells were rinsed three times with culture medium and plated on a poly-L-lysine (Sigma)-coated well $\left(0.32 \mathrm{~cm}^{2}\right)$ at a final density of $0.5-1.5 \times 10^{6}$ cells per ml. The culture was maintained for $7 \mathrm{~d}$ with defined culture medium: DMEM supplemented with $1 \mathrm{mg} / \mathrm{ml}$ bovine serum albumin, $10 \mu \mathrm{g} / \mathrm{ml}$ insulin, $1 \mathrm{nM} 3,3$, 5 -triiodo-L-thyronine, $0.1 \mathrm{mg} / \mathrm{ml}$ human transferrin, $1 \mu \mathrm{g} / \mathrm{ml}$ aprotinin, $100 \mu \mathrm{M}$ putrescine, $1 \mathrm{~mm}$ sodium pyruvate, $10 \mathrm{nM}$ progesterone, $30 \mathrm{~nm}$ selenium, $0.1 \mathrm{mg} / \mathrm{ml}$ streptomycin sulfate, 50 units $/ \mathrm{ml}$ penicillin $\mathrm{G}$ potassium salt (Meiji Seika Kaisha, Ltd., Tokyo, Japan) in a humidified atmosphere of $5 \% \mathrm{CO}_{2}$ in air at $37^{\circ} \mathrm{C}$

Representative cultures were stained to determine the relative proportions of glia. Glia were labeled by staining with immunohistochemical staining kit for glial fibrillary acidic protein (Biomeda Corp., Foster City, CA).

${ }^{3} H$-TCP intact cell binding. After removal of the media, the cells were washed three times with CMF-PBS. After the addition of $75 \mu \mathrm{l}$ of Locke medium of modified composition (LMC) [(in mM) NaCl, 154; KCl, 5.6; $\mathrm{CaCl}_{2}, 1.8$; sucrose, 1; $\mathrm{NaHCO}_{3}, 6$; and glucose, 10; TTX 0.0005; buffered to $\mathrm{pH} 7.2$ with $2 \mathrm{mM}$ HEPES], the cells were preincubated with or without the drugs dissolved in $0.32 \mathrm{~m}$ sucrose solution except for NMDA and $\mathrm{Mg}^{2+}$ for $30 \mathrm{~min}$ in a humidified atmosphere of $5 \% \mathrm{CO}_{2}$ in air at $37^{\circ} \mathrm{C}$

The binding was started by the addition of $25 \mu \mathrm{l}$ of $20 \mathrm{~nm}$ of ${ }^{3} \mathrm{H}-\mathrm{TCP}$ with or without NMDA and $\mathrm{Mg}^{2+}$ in $\mathrm{LMC}$ in an atmosphere consisting of $95 \% \mathrm{O}_{2}: 5 \% \mathrm{CO}_{2}$ at $25^{\circ} \mathrm{C}$ (total volume; $100 \mu \mathrm{l} /$ well), and was terminated by rapid aspiration of the media, followed by washing four times with ice-cold CMF-PBS in $10 \mathrm{sec}$. The cells were solubilized by the addition of $150 \mu \mathrm{l}$ of $0.1 \mathrm{M} \mathrm{NaOH}$. The resulting aliquot $(100 \mu \mathrm{l})$ was neutralized with $0.1 \mathrm{M} \mathrm{HCI}$, and the radioactivity was measured by liquid scintillation spectrophotometry (Beckman LS 9800) (Beckman, Fullerton, CA) in a $3 \mathrm{ml}$ of Aquasol (New England Nuclear, Boston, MA) at a counting efficiency of $45-50 \%$. Nonspecific binding was determined by the addition of PCP $(1 \mathrm{mM})$. Protein concentrations were determined using the Bio-Rad protein assay kit (Bio-Rad, Richmond, VA).

Binding of ${ }^{3} \mathrm{H}-T C P$ to the membrane preparation. Binding of ${ }^{3} \mathrm{H}-\mathrm{TCP}$ to the membrane preparation was also examined. Extensively washed synaptic membranes were prepared from the cerebral cortex of male Wistar rats each weighing $150-250 \mathrm{gm}$, according to the method described in detail elsewhere (Hori et al., 1990). In brief, the cortical tissue was homogenized in ice-cold $0.32 \mathrm{M}$ sucrose and centrifuged at $900 \times$ $g$ for $10 \mathrm{~min}$ at $4^{\circ} \mathrm{C}$. The supernatant was centrifuged at $20,000 \times g$ for $20 \mathrm{~min}$ at $4^{\circ} \mathrm{C}$, and the crude synaptosomal membrane obtained was suspended in $50 \mathrm{~mm}$ Tris- $\mathrm{HCl}$ buffer containing $10 \mathrm{~mm}$ EDTA ( $\mathrm{pH} 7.6$ ), preincubation for $10 \mathrm{~min}$ at $37^{\circ} \mathrm{C}$, and centrifuged at $20,000 \times g$ for 20 min at $4^{\circ} \mathrm{C}$. The resulting pellet was resuspended in the same buffer and quickly frozen, followed by thawing and centrifugation at $20,000 \times g$ for $20 \mathrm{~min}$ at $4^{\circ} \mathrm{C}$. The resulting pellet was resuspended in $5 \mathrm{~mm}$ Tris$\mathrm{HCl}$ buffer ( $\mathrm{pH} 7.6)$, frozen, and stored at $-80^{\circ} \mathrm{C}$ for at least $24 \mathrm{hr}$ prior to the binding assay. On the day of the experiment, the membrane was thawed at room temperature and washed twice with the assay buffer ( 5 mм Tris-HEPES buffer, $\mathrm{pH}$ 7.6). Finally, the resulting pellet was resuspended in the assay buffer.

The membrane homogenates in the assay buffer $(8-10 \mu \mathrm{g}$ protein in a final volume of $200 \mu \mathrm{l}$ ) were incubated with $5 \mathrm{nM}{ }^{3} \mathrm{H}-\mathrm{TCP}$ for $60 \mathrm{~min}$ at $25^{\circ} \mathrm{C}$. The incubation was terminated by rapid vacuum filtration through Whatman GF/C filters, using an Inotech Cell Harvester (Wohlen, Switzerland), followed by washing 10 times with ice-cold $5 \mathrm{~mm}$ Tris-HEPES buffer (pH 7.6). To reduce adsorption to them, the glass filters were presoaked for $15-20 \mathrm{~min}$ in $0.05 \%$ polyethylenimine before filtration. The radioactivity bound to the filters was measured by liquid scintillation spectrometry carried out in $3 \mathrm{ml}$ of Aquasol, as mentioned above. Protein concentrations were determined as described by Lowry et al. (1951) using bovine serum albumin as the standard.

Statistics. Comparisons between groups were made using Student's $t$ test (two tailed). Equilibrium saturation and drug competition binding data were analyzed with the iterative curve-fitting computer programs EBDA (McPherson, 1983) and LIGAND (Munson and Rodbard, 1980).

\section{Results}

More than $95 \%$ of the cultured cells used were non-GFAP immunoreactive when the positive control of cultured glial cells was stained well. Thus, the cultured neuronal cells used seemed to be suitable for studying ${ }^{3} \mathrm{H}-\mathrm{TCP}$ binding to intact cell binding.

As shown in Figure $1 A$, specific ${ }^{3} \mathrm{H}-\mathrm{TCP}$ intact cell binding was time dependent, an equilibrium being reached starting at 7 min. Thus, an incubation time of $10 \mathrm{~min}$ was used in subsequent experiments. The total binding was approximately $300-1000$ d.p.m. per well. Nonspecific binding represents only $3.0-5.4 \%$ of the total binding at $5 \mathrm{~nm}{ }^{3} \mathrm{H}-\mathrm{TCP}$. The dissociation reaction was initiated by the addition of excess of either PCP $(100 \mu \mathrm{M})$ or haloperidol $(100 \mu \mathrm{M})$. PCP more quickly and markedly stimulated dissociation of ${ }^{3} \mathrm{H}-\mathrm{TCP}$ from the intact cells than haloperidol (Fig. $1 B$ ).

In a previous study, we showed that L-glutamate stimulated ${ }^{3} \mathrm{H}$-TCP binding to extensively washed rat cortical membranes in a concentration-dependent manner, with a maximal effect, occurring in the concentration range of $10-100 \mu \mathrm{M}$, approximately $700 \%$ of the basal binding (Hori et al., 1990). On the other hand, $\mathrm{Mg}^{2+}$ had a biphasic effect on ${ }^{3} \mathrm{H}-\mathrm{TCP}$ binding, i.e., a stimulatory effect at low concentrations and an inhibitory effect at high concentrations (Hori et al., 1991). Thus, we examined the effects of both L-glutamate and $\mathrm{Mg}^{2+}$ on the ${ }^{3} \mathrm{H}$-TCP binding to the intact neuronal cells. In contrast to the ${ }^{3} \mathrm{H}-\mathrm{TCP}$ binding to the membrane preparation, L-glutamate, at a concentration of $0.5 \mathrm{~mm}$, had no stimulatory effect on the ${ }^{3} \mathrm{H}-\mathrm{TCP}$ intact cell binding compared to the control binding (Fig. $2 B$ ). Similarly, $\mathrm{Mg}^{2+}$ at low concentrations did not stimulate ${ }^{3} \mathrm{H}-\mathrm{TCP}$ intact cell binding in either the presence or absence of $0.5 \mathrm{mM} \mathrm{L-glu-}$ tamate, whereas $\mathrm{Mg}^{2+}$ concentrations higher than $1 \mathrm{~mm}$ inhibited ${ }^{3} \mathrm{H}$-TCP binding (Fig. $2 A, B$ ). It should be noted that in both the absence or the presence of $0.5 \mathrm{~mm}$ L-glutamatc, a sclcctivc NMDA antagonist, APV (1 mM), inhibited ${ }^{3} \mathrm{H}-\mathrm{TCP}$ binding to the intact cells (Fig. $2 B$ ). Scatchard analysis of the saturation data indicated a single class of binding sites for ${ }^{3} \mathrm{H}-\mathrm{TCP}$ in the intact cells with a $K_{d}=25.8 \pm 3.4 \mathrm{nM}$ and a $B_{\max }=6.62 \pm 0.35$ $\mathrm{pmol} / \mathrm{mg}$ protein $(N=7)$ (Fig. 3). The addition of $3 \mu \mathrm{M}$ haloperidol markedly reduced the density of the NMDA receptorion channel complex on the intact cells without affecting the affinity of ${ }^{3} \mathrm{H}$-TCP for its binding sites. By contrast, the addition 
(A)

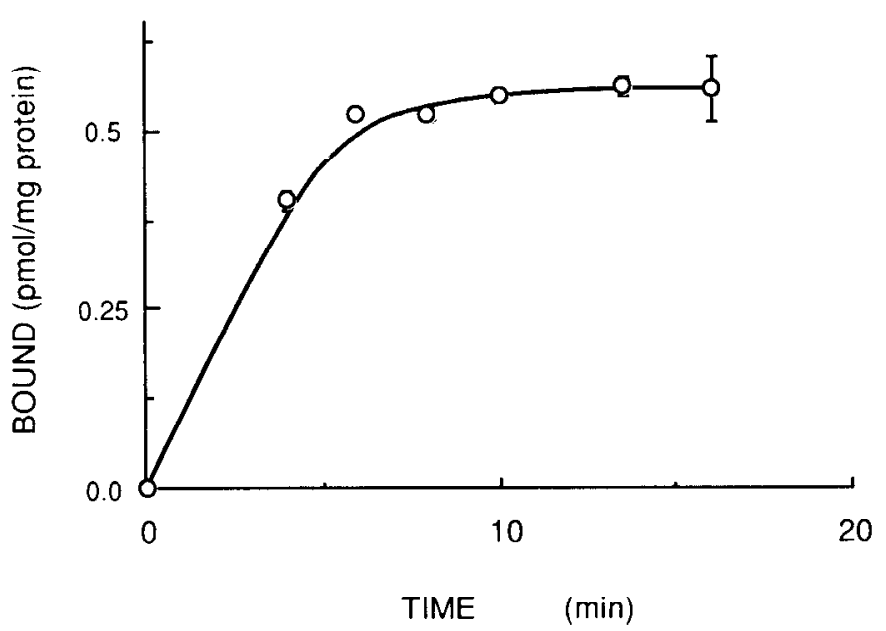

(B)

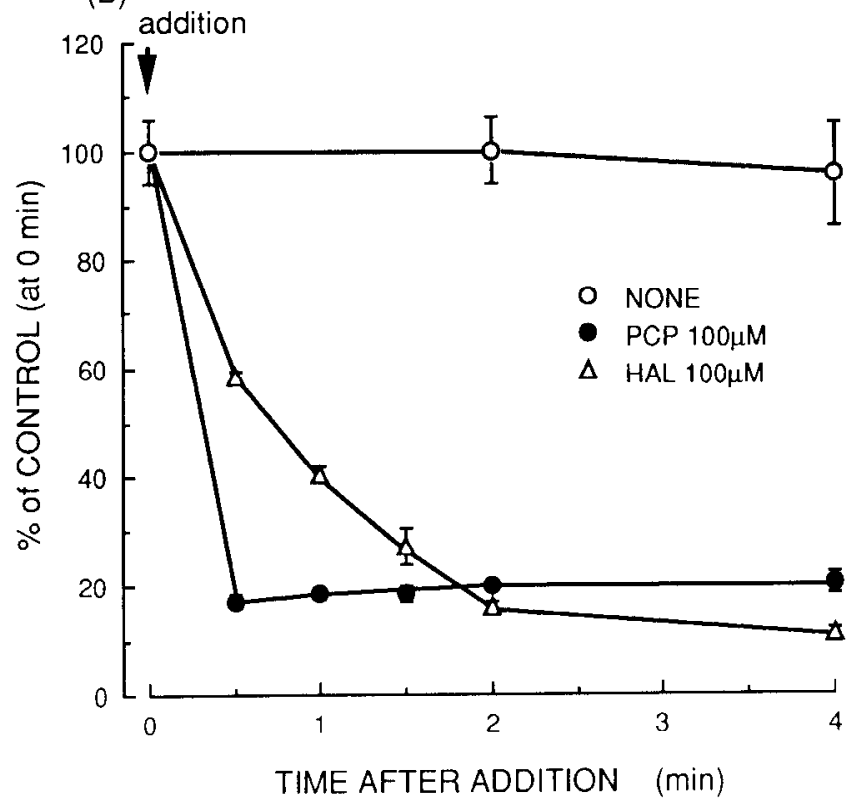

Figure 1. Association $(A)$ and dissociation $(B)$ curves for the binding of ${ }^{3} \mathrm{H}$-TCP to the primary neuronal cultured cells at $25^{\circ} \mathrm{C}$. As described in Materials and Methods, cells were incubated with $5 \mathrm{nM}{ }^{3} \mathrm{H}-\mathrm{TCP}$ until reaching an equilibrium, followed further incubation with $100 \mu \mathrm{M}$ of PCP or haloperidol, and then quickly washed and harvested. Each value is the average of triplicate determinations from a representative experiment that was repeated three times with similar results.

of $3 \mu \mathrm{M}( \pm) \mathrm{MK} 801$ reduced the affinity of ${ }^{3} \mathrm{H}-\mathrm{TCP}$ binding sites without affecting receptor density.

Both antagonists of the NMDA receptor-ion channel complex and $\sigma$ ligands were examined for thcir inhibition of ${ }^{3} \mathrm{H}-\mathrm{TCP}$ binding to the intact cells. All the drugs tested had inhibitory effects, although MK-801 and (+)pentazocine at low concentrations (100 nM) stimulated ${ }^{3} \mathrm{H}-\mathrm{TCP}$ binding (Fig. $4 A, B$ ), and the slope factors calculated using the LIGAND program (Hill coefficients) were in the range of $0.830-1.386$. Of all the drugs tested, dextromethorphan $\left(\mathrm{IC}_{50}=1.760 \pm 0.41 \mu \mathrm{M}\right)$ caused the greatest inhibition of ${ }^{3} \mathrm{H}-\mathrm{TCP}$ intact cell binding. Haloperidol $\left(\mathrm{IC}_{50}=1.863 \pm 0.391 \mu \mathrm{M}\right)$ inhibited ${ }^{3} \mathrm{H}-\mathrm{TCP}$ binding to a similar extent as well. The order of inhibition was dextromethorphan, haloperidol $>( \pm)$ MK-801 $>(+)$ pentazocine $>(-)$ pentazocine
(A)

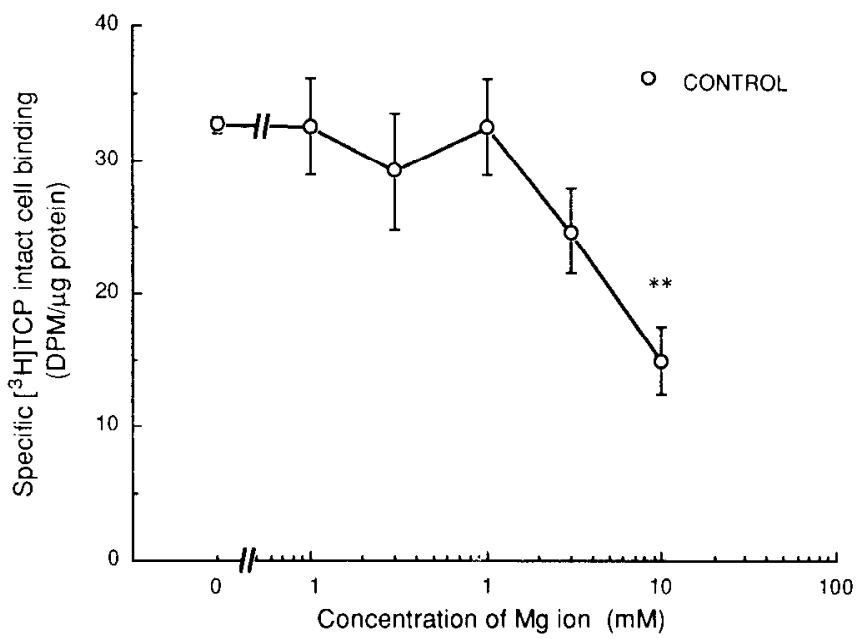

(B)

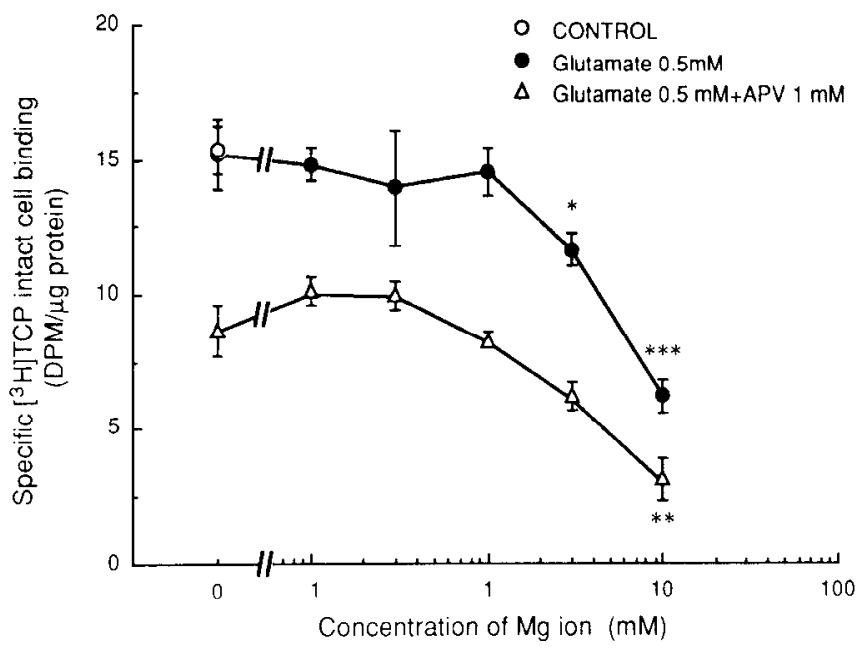

Figure 2. Effect of $\mathrm{Mg}^{2+}(A)$, glutamate, and an NMDA receptor antagonist APV $(B)$ on ${ }^{3} \mathrm{H}-\mathrm{TCP}$ intact cell binding. ${ }^{3} \mathrm{H}-\mathrm{TCP}$ intact cell binding assays were conducted with increasing concentrations of magnesium ion. Each value is the average of triplicate $(A)$ and quadruplicate $(B)$ determinations from a representative experiment that was repeated two times with similar results.

$>$ DTG $>$ PCP $>(+)$ SKF $10047>(+) 3-$ PPP $>(-)$ SKF 10047 $>(-) 3$ PPP (Table 1). The $(+)$ isomers of the $\sigma$ drugs were more potent than their $(-)$ isomers. Representative NMDA antagonists and $\sigma$ ligands were also examined for their ability to inhibit ${ }^{3} \mathrm{H}-\mathrm{TCP}$ binding to an extensively washed rat cortical membrane preparation. Inhibition of ${ }^{3} \mathrm{H}$-TCP binding to the membrane preparation by $( \pm) \mathrm{MK}-801$ and $\mathrm{PCP}$ was 253 and 500 times higher than their inhibitory effects on ${ }^{3} \mathrm{H}-\mathrm{TCP}$ intact cell binding, respectively. DTG and (+)SKF 10047 were less effective in inhibiting ${ }^{3} \mathrm{H}-\mathrm{TCP}$ intact cell binding. By contrast, the inhibitory effect of haloperidol on ${ }^{3} \mathrm{H}-\mathrm{TCP}$ intact cell binding was 10 times greater than that on ${ }^{3} \mathrm{H}-\mathrm{TCP}$ binding to rat cortical membranes.

The $\mathrm{IC}_{50}$ values of six $\sigma$ ligands obtained from the inhibition curves in the ${ }^{3} \mathrm{H}$-TCP intact cell binding study were compared with the inhibitory dissociation constants ( $K_{i}$ values) of the corresponding drugs for DTG site 1 in the guinea pig brain reported 


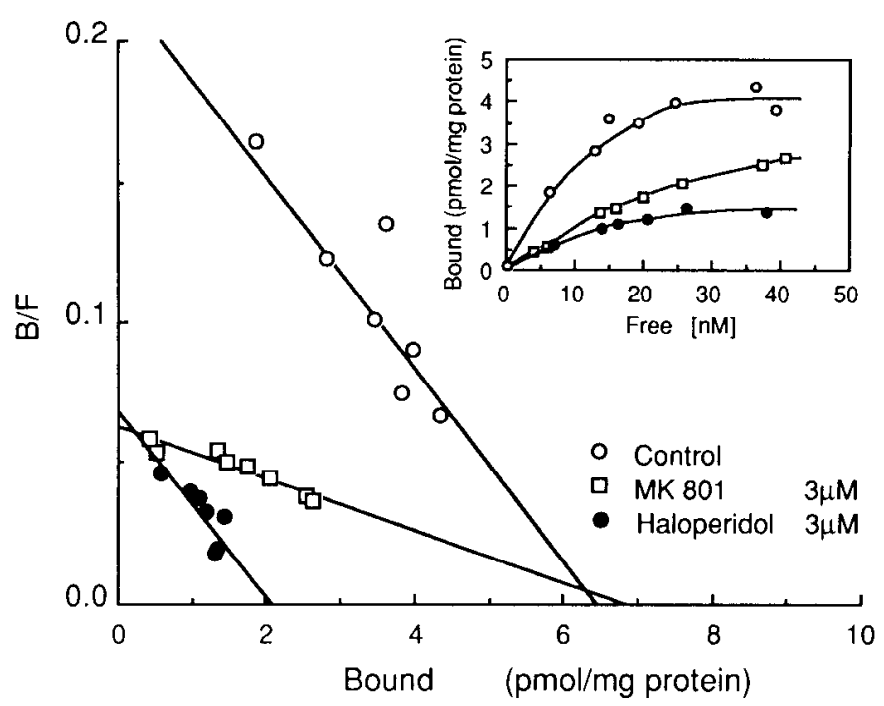

Figure 3. Scatchard plot of ${ }^{3} \mathrm{H}-\mathrm{TCP}$ intact cell binding of primary cultured neuron with or without $3 \mu \mathrm{M}$ of haloperidol or $( \pm) \mathrm{MK} 801$. The results are the average of triplicate determinations from a representative experiment that was performed three times. The values for the density of binding sites $\left(B_{\text {max }}\right)$ were $6.62 \pm 0.35 \mathrm{pmol} / \mathrm{mg}$ protein (control) $(N-7), 1.59 \pm 0.27 \mathrm{pmol} / \mathrm{mg}$ protein (with haloperidol) $(N$ $=5$ ), and $7.61 \pm 0.61 \mathrm{pmol} / \mathrm{mg}$ protein $[$ with $( \pm) M K 801](N=3)$, and those for the equilibrium dissociation constant $\left(K_{d}\right)$ were $25.8 \pm 3.4$ nм (control), $25.5 \pm 7.3 \mathrm{~nm}$ (with haloperidol), and $62.6 \pm 12.3 \mathrm{~nm}$ [with $( \pm) M K 801]$.

by Rothman et al. (1991). There was a good correlation between the $\mathrm{IC}_{50}$ and the $K_{i}$ values $(r=0.90)$ (Fig. 5).

\section{Discussion}

The present findings were, in most respects, consistent with the observations obtained from the ${ }^{3} \mathrm{H}-\mathrm{TCP}$ binding studies using membrane preparations. However, ${ }^{3} \mathrm{H}-\mathrm{TCP}$ intact cell binding reached equilibrium faster than ${ }^{3} \mathrm{H}$-TCP binding to the membrane preparation (Hori et al., 1990). The findings that L-glutamate and glycine stimulated ${ }^{3} \mathrm{H}-\mathrm{TCP}$ binding to extensively washed rat cortical membranes (Hori et al., 1991), suggest acceleration of ${ }^{3} \mathrm{H}-\mathrm{TCP}$ intact cell binding by endogenous amino acids, such as L-glutamate and glycine, derived from the intact

Table 1. Comparisons of $\mathrm{IC}_{50}$ values in inhibiting ${ }^{3} \mathrm{H}-\mathrm{TCP}$ binding obtained from studies using intact neuronal cells or membrane preparation of rat brain

\begin{tabular}{lrl} 
Drugs & \multicolumn{1}{c}{$\mathrm{IC}_{50}$ from intact cells } & \multicolumn{1}{l}{$\mathrm{IC}_{50}$ from membranes } \\
\hline Dextromethorphan & $1.760 \pm 0.410(7)$ & n.d. \\
( \pm MK 801 & $2.025 \pm 0.445(8)$ & $0.008 \pm 0.003(4)$ \\
PCP & $12.478 \pm 2.354(4)$ & $0.025 \pm 0.003(4)$ \\
Haloperidol & $1.863 \pm 0.391(7)$ & $18.880 \pm 1.410(4)$ \\
(+)Pentazocine & $4.572 \pm 0.608(4)$ & n.d. \\
(-)Pentazocine & $7.147 \pm 3.163(4)$ & n.d. \\
DTG & $10.207 \pm 1.443(6)$ & $4.747 \pm 0.988(4)$ \\
$(+)$ SKF10047 & $14.654 \pm 3.052(9)$ & $0.274 \pm 0.093(4)$ \\
$(+) 3-P P P$ & $17.581 \pm 4.519(6)$ & n.d. \\
$(-)$ SKF10047 & $20.476 \pm 4.800(9)$ & n.d. \\
$(-) 3-P P P$ & $27.072 \pm 3.140(5)$ & n.d.
\end{tabular}

$\overline{\text { Values }(\mu \mathrm{M}) \text { indicate mean } \pm \text { SEM of four to nine independent experiments, each }}$ conducted in triplicate. n.d., not determined.
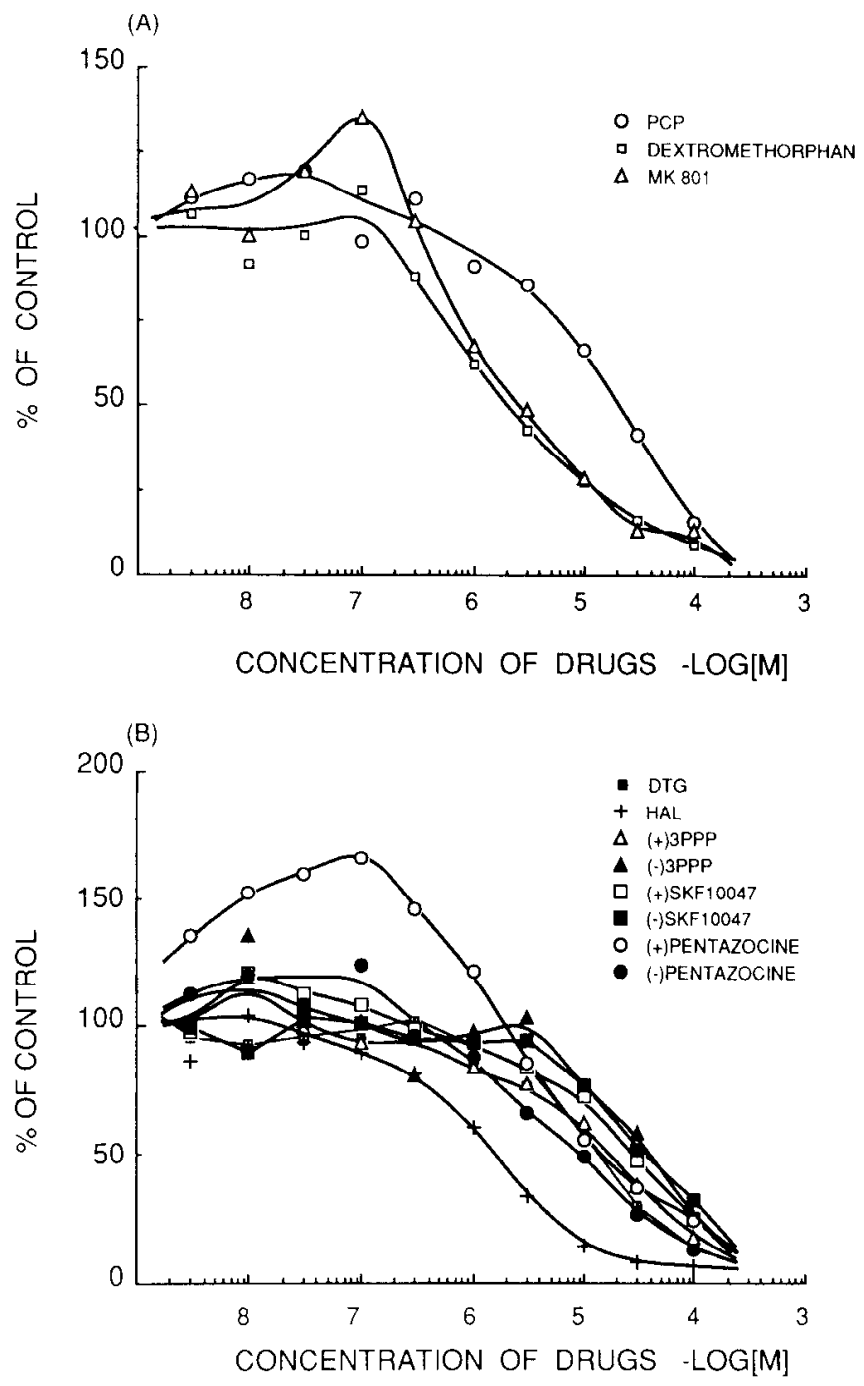

Figure 4. Competition curves of ${ }^{3} \mathrm{H}-\mathrm{TCP}(5 \mathrm{nM})$ binding of intact neuronal cells by increasing concentrations of known NMDA receptorion channel complex blockers, including PCP, dextromethorphan, and MK $801(A)$ or $\sigma$ ligands including DTG, haloperidol, 3-PPPs, SKF $10047 \mathrm{~s}$, and pentazocines $(B)$. Each value shows the average of four to nine separate experiments performed in triplicate.

cells in the assay medium. This view is supported by our present observations not only that the addition of $0.5 \mathrm{~mm}$ of L-glutamate did not stimulate the ${ }^{3} \mathrm{H}$-TCP binding to the intact cells, but also that a selective and competitive NMDA receptor antagonist, APV, decreased ${ }^{3} \mathrm{H}$-TCP intact cell binding in the absence of both $\mathrm{L}$-glutamate and $\mathrm{Mg}^{2+}$

$\mathrm{Mg}^{2+}$ inhibits ${ }^{3} \mathrm{H}-\mathrm{TCP}$ binding noncompetitively (Vignon et al., 1982). In addition, electrophysiological and biochemical studies have shown that $\mathrm{Mg}^{2+}$ recognition sites exist in the ion channel and an inhibitory effect of $\mathrm{Mg}^{2+}$ on ${ }^{3} \mathrm{H}-\mathrm{TCP}$ binding is exerted through these $\mathrm{Mg}^{2+}$ recognition sites (Mayer et al., 1984; Nowak et al., 1984; Foster and Fagg, 1987; Kemp et al., 1987; Reynolds and Miller, 1988). The present finding that $\mathrm{Mg}^{2+}$ concentrations higher than $1 \mathrm{~mm}$ inhibited ${ }^{3} \mathrm{H}$-TCP intact cell binding is in good agreement with the previous findings obtained in binding studies using either well-washed or crude membrane preparations. The above-mentioned findings, i.e., that L-glutamate did not stimulate ${ }^{3} \mathrm{H}$-TCP binding to the intact cells and 


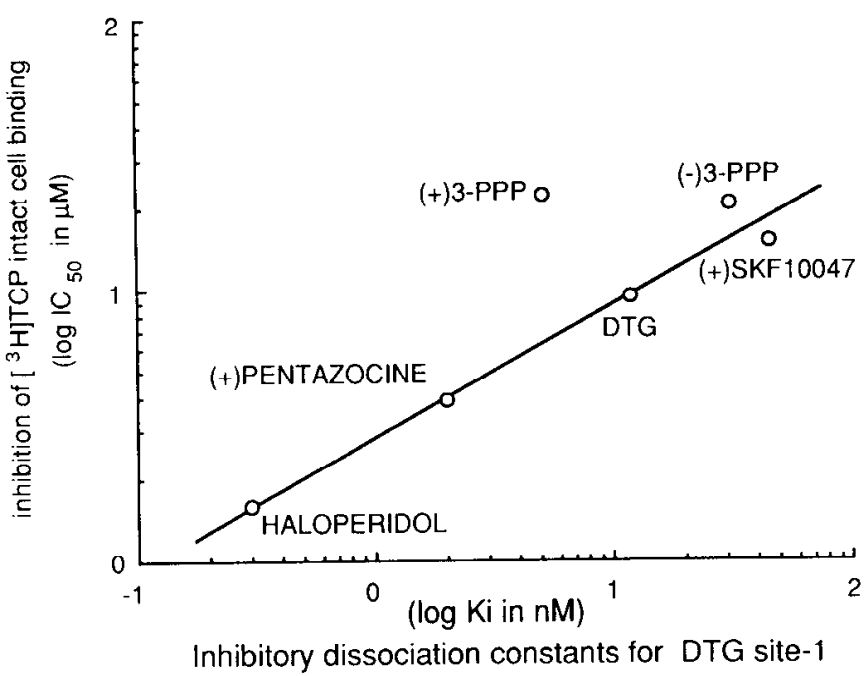

Figure 5. Correlation between the DTG site 1 binding potency from another laboratory's studies (Rothman et al., 1991) and potency in inhibiting ${ }^{3} \mathrm{H}-\mathrm{TCP}$ intact cell binding of primary cultured neuronal cells.

that $\Lambda P V$ decreased ${ }^{3} \mathrm{H}$-TCP intact cell binding, suggest that ${ }^{3} \mathrm{H}-$ TCP binding to primary cultured neuronal cells reflects in vivo ${ }^{3} \mathrm{H}-\mathrm{TCP}$ binding to the NMDA receptor-ion channel complex.

Noncompetitive NMDA receptor antagonists, MK 801 and $\mathrm{PCP}$, inhibited the specific binding of ${ }^{3} \mathrm{H}$-TCP to the intact cells. However, the inhibitory effects of these two antagonists on ${ }^{3} \mathrm{H}$ TCP intact cell binding were much weaker than their inhibitory effects on ${ }^{3} \mathrm{H}$-TCP binding to membrane preparations. Previously, we reported that monovalent cations, $\mathrm{Na}^{+}$and $\mathrm{K}^{+}$, inhibited ${ }^{3} \mathrm{H}$-TCP binding to well-washed membranes in a concentration-dependent manner (Hatta et al., 1991). Considering that intact cell binding occurred in $\mathrm{LMC}, \mathrm{NaCl}(150 \mathrm{~mm})$ and $\mathrm{KCl}(5.6 \mathrm{mM})$ in the LMC may have inhibited ${ }^{3} \mathrm{H}-\mathrm{TCP}$ intact cell binding more strongly than ${ }^{3} \mathrm{H}$-TCP binding to membrane preparations in $5 \mathrm{~mm}$ Tris-HEPES buffer alone.

In most previous ligand-binding studies using membrane preparations, specific $\sigma$ ligands have been reported to display low affinity for sites labeled by ${ }^{3} \mathrm{H}-\mathrm{TCP}$ (Quirion et al., 1987; Deutsch et al., 1988; Church and Lodge, 1990; Sanger and Joly, 1991). The most pronounced difference between ${ }^{3} \mathrm{H}-\mathrm{TCP}$ intact cell binding and ${ }^{3} \mathrm{H}-\mathrm{TCP}$ binding to membrane preparations is that even though they have low affinity for the NMDA receptorion channel complex, $\sigma$ ligands, especially haloperidol, inhibited ${ }^{3} \mathrm{H}-\mathrm{TCP}$ intact cell binding in a noncompetitive manner. Furthermore, it should be noted that although its underlying mechanism is not clear, displacement of ${ }^{3} \mathrm{H}$-TCP from its specific binding sites by haloperidol was somewhat slower than that by PCP. These findings suggest that $\sigma$ ligands could indirectly modulate the NMDA receptor-ion channel complex on the intact cells. In other words, it seems possible that $\sigma$ ligands indirectly modulate the NMDA receptor-ion channel complex through $o$ binding sites in vivo. In addition, the present observations that, although $( \pm)$ MK 801 and (+)pentazocine stimulated ${ }^{3} \mathrm{H}-\mathrm{TC} P$ intact cell binding at low concentrations, the $\mathrm{IC}_{50}$ values of several test drugs for ${ }^{3} \mathrm{H}$-TCP binding were closely correlated with the $K_{i}$ values of the corresponding drugs for ${ }^{3} \mathrm{H}-\mathrm{DTG}$ site 1 , which is regarded as the same as the DM $1 / \sigma 1$ site (Rothman et al., 1991) provides supporting evidence for our above-mentioned view and, furthermore, suggests that $\sigma$ ligands indirectly act on the NMDA receptor-ion channel complex through $\sigma 1$ sites.

Recently, electrophysiological studies (Chen and Huang, 1991, 1992 ) have shown that protein kinase $C(P K C)$ potentiates the NMDA response by increasing the probability of channel openings and by reducing the vollage-dependent $\mathrm{Mg}^{2+}$ block of the ion channel of the NMDA receptor-ion channel complex. Furthermore, Kitamura et al. (1993) have reported that pretreatment with purified type II of PKC and $\mathrm{Ca}^{2+} /$ calmodulin-dependent PK-II (CaMK-II)-catalyzed phosphorylation enhanced the L-glutamate-induced increase of ${ }^{3} \mathrm{H}-\mathrm{MK}-801$ binding, suggesting that PKC-II and/or CaMK-II induce the phosphorylation of the channel domain of the NMDA receptor-ion channel complex.

Bowen ct al. (1988, 1989) have shown that $\sigma$ ligands, such as (+)pentazocine, DTG, and haloperidol, inhibit carbachol-stimulated phosphoinositide (PI) turnover in a dose-dependent manner, suggesting that $\sigma$ ligands block the activation of phospholipase $C$ induced by $G$-protein-coupled muscarinic receptors. On the other hand, PKC activation is often associated with PI hydrolysis, that is, the products of PI hydrolysis, diacylglycerols, cause PKC activation (Takai et al., 1979; Kishimoto et al., 1980). These findings suggest that $\sigma$ ligands exert inhibitory effects on channel openings of the NMDA receptor-ion channel complex by inhibition of phosphorylation through a mechanism(s) in which phospholipase $C$ is involved. However, further studies are necessary to elucidate the mechanisms of the inhibitory effects of $\sigma$ ligands on the NMDA receptor-ion channel complex.

In conclusion, the present study showed that the $\sigma$ ligands tested inhibited ${ }^{3} \mathrm{H}$-TCP intact cell binding and that the $\mathrm{IC}_{30}$ values of several test drugs for ${ }^{3} \mathrm{H}-\mathrm{TCP}$ binding were closely correlated with the $K_{i}$ values of the corresponding drugs for ${ }^{3} \mathrm{H}$ DTG site 1 , which is regarded as the $\sigma$ l site. Based on these findings, we postulated that $\sigma$ ligands indirectly modulate the NMDA receptor-ion channel complex through the $\sigma \mathrm{l}$ site in vivo.

\section{References}

Bowen WD, Kirschner BN, Newman AH, Rice KC (1988) Sigma receptors negatively modulate agonist-stimulated phosphoinositide metabolism in rat brain. Eur J Pharmacol 149:399-400.

Bowen WD, Tolentino P, Varghese P (1989) Investigation of the mechanism by which sigma ligands inhibit stimulation of phosphoinositide metabolism by muscarinic cholinergic agonists. Prog Clin Biol Res 328:21-24

Chen L, Huang L-YM (1991) Sustained potentiation of NMDA receptor-mediated glutamate responses through activation of protein kinase $C$ by a $\mu$ opioid. Neuron 7:319-326.

Chen L, Huang L-YM (1992) Protein kinase C reduces $\mathbf{M g}^{2+}$ block of NMDA receptor channels as a mechanism of modulation. Nature 356:521-523.

Church J, Lodge D (1990) Failure of sigma-receptor ligands to reduce the excitatory actions of $N$-methyl-DL-aspartate on rat spinal neurons in vivo. J Pharm Pharmacol 42:56-57.

Deutsch SI, Weizman A, Goldman ME, Morihisa JM (1988) The sigma receptor: a novel site implicated in psychosis and antipsychotic drug efficacy. Clin Neuropharmacol 11:105-119.

Fcrris CD, Hirsch DJ, Brooks BP, Snyder SH (1991) Sigma receptors: from molecule to man. J Neurochem 57:729-737.

Foster AC, Fagg GE (1987) Taking apart NMDA receptors. Nature 329:395-396.

Hatta K, Yamamoto T, Hori T, Okuwa M, Moroji T (1991) Characterization of the high affinity $\mathrm{Mg}^{2+}$ site on the NMDA/PCP receptor-ion channel complex: interactions with recognition sites for NMDA and glycine. In: NMDA receptor related agents: biochemistry, phar- 
macology and behavior (Kameyama $T$, Nabeshima $T$, Domino EF, eds), pp 53-62. Ann Arbor, MI: NPP.

Hori T, Yamamoto T, Hatta K, Moroji T (1990) Biphasic effects of magnesium on the $\left[{ }^{3} \mathrm{H}\right] \mathrm{N}-(1-(2-$ thienyl)cyclohexyl)-3,4-piperidine binding in the rat cerebral cortex. Neurosci Lett 119:9-11.

Hori T, Yamamoto T, Hatta K, Moroji T (1991) Modulation of $\mathrm{Mg}^{2+}$. dependent $\left[{ }^{3} \mathrm{H}\right] \mathrm{TCP}$ binding by L-glutamate, glycine, and guanine nucleotides in rat cerebral cortex. Synapse 8:13-21.

Kemp J A, Foster AC, Wong EHF (1987) Non-competitive antagonists of excitatory amino acid receptor. Trends Neurosci 10:294-298.

Kishimoto A, Takai Y, Mori T, Kikkawa U, Nishizuka Y (1980) Aclivation of calcium and phospholipid-dependent protein kinase by diacylglycerol, its possible relation to phosphatidylinositol turnover. J Biol Chem 255:2273-2276.

Kitamura Y, Miyazaki A, Yamanaka Y, Nomura Y (1993) Stimulatory effects of protein kinase $\mathrm{C}$ and calmodulin kinase II on $\mathrm{N}$-methylD-aspartate receptor/channels in the postsynaptic density of rat brain. J Neurochem 61:100-109.

Largent BL, Gundlach AL, Snyder SH (1986) Pharmacological and autoradiographic discrimination of sigma and phencyclidine receptor binding sites in brain with $(+)\left[{ }^{3} \mathrm{H}\right] \mathrm{SKF} 10047,(+)-\left[{ }^{3} \mathrm{H}\right]-3$-[hydroxyphenyl]- $N$-(1-propyl) piperidine and $\left[{ }^{3} \mathrm{H}\right]-1-\left[1-\left(2-t_{\text {thien- }}\right.\right.$ yl)cyclohexyl]-piperidine. J Pharmacol Exp Ther 238:739-748.

Lowry OH, Rosebrough NJ, Farr AL, Randall RJ (1951) Protein measurement with the Folin phenol reagent. J Biol Chem 193:265275.

Malouf AT, Swearengen E, Chavkin C (1988) Comparison of the actions of phencyclidine and sigma ligands on CAI hippocampal pyramidal neurons in the rat. Neuropharmacology 27:1161-1170.

Mayer ML, Westbrook GL, Guthrie PB (1984) Voltage-dependent block by $\mathrm{Mg}^{2+}$ of NMDA responses in spinal cord neurons. Nature 306:261-263.

McPherson GA (1983) A practical computer-based approach to the analysis of radioligand binding experiments. Comput Programs Biomed 17:107-114.

Monnet FP, Debonnel G, De Montigny C (1992) In vivo electrophysiological evidence for a selective modulation of $N$-methyl-Daspartate-induced neuronal activation in rat CA3 dorsal hippocampus by sigma ligands. J Pharmacol Exp Ther 261:123-130.

Munson PJ, Rodbard D (1980) LIGAND: a versatile computerized ap- proach for characterization of ligand-binding systems. Anal Biochem 107:220-239.

Nowak L, Bregestovski P, Ascher P, Herbet A, Prochiantz Z (1984) Magnesium gates glutamate-activated channels in mouse central neurons. Nature 307:462-465.

Quirion R, Chicheportiche PC, Contreras KM, Johnson D, Lodge S, Tam W, Woods JH, Zukin SR (1987) Classification and nomenclature of phencyclidine and sigma receptor sites. Trends Pharmacol Sci 10:444-446.

Reynolds IJ, Miller RJ (1988) Multiple sites for the regulation of the $N$-methyl-D-aspartate receptor. Mol Pharmacol 33:581-584.

Rothman RB, Reid A, Mahboubi A, Chong-Ho K, De Costa BR, Jacobson AE, Rice KC (1991) Labeling by $\left[{ }^{3} \mathrm{H}\right] 1$,3-di(2-tolyl) guanidine of two high affinity binding sites in guinea pig brain: evidence for allosteric regulation by calcium channel antagonists and pseudoallosteric modulation by sigma ligands. Mol Pharmacol 39:222232.

Sanger DJ, Joly D (1991) Effects of NMDA receptor antagonists and sigma ligands on the acquisition of conditioned fear in mice. Psychopharmacology (Rerlin) 104:27-34.

Su T-P (1982) Evidence for sigma opioid receptor: binding of [ $\left.{ }^{3} \mathrm{H}\right] \mathrm{SKF}$ 10047 to etorphine-inaccessible sites in guinea-pig brain. J Pharmacol Exp Ther 223:284-290.

Takai Y, Kishimoto A, Iwasa Y, Kawahara Y, Mori T, Nishizuka Y (1979) Calcium-dependent activation of a multifunctional protein kinase by membrane phospholipids. J Biol Chem 254:3692-3695.

Tam SW, Cook L (1984) Sigma opiates and certain antipsychotic drugs mutually inhibit $(+)-\left[{ }^{3} \mathrm{H}\right] \mathrm{SKF} 10,047$ and $\left[{ }^{3} \mathrm{H}\right]$ haloperidol binding in guinea pig membranes. Proc Natl Acad Sci USA 81:5618-5621.

Vignon J, Vincent JP, Bidard JN, Kamenka JM, Geneste P, Monier S, Lazdunski M (1982) Biochemical properties of the brain phencyclidine receptor. Eur J Pharmacol 81:531-542.

Walker JM, Bowen WD, Walker FO, Matsumoto RR, De Costa B, Rice KC (1990) Sigma receptors: biology and function. Pharmacol Rev 42:355-402.

Yuzaki M, Miyawaki A, Akita K, Kudo Y, Ogura A, Ino H, Mikosiba K (1990) Mode of blockade by MK-801 of $N$-methyl-D-aspartateinduced increase in intracellular $\mathrm{Ca}^{2+}$ in cultured mouse hippocampal neurons. Brain Res 517:51-56. 